\title{
Rethinking Nature-Based Approaches in Early Childhood Education: Common Worlding Practices
}

\author{
Narda Nelson, Veronica Pacini-Ketchabaw, and Fikile Nxumalo
}

\begin{abstract}
Narda Nelson is a master's student in the School of Child and Youth Care, University of Victoria, located on the traditional territories of Lekwungen-speaking peoples. Drawing on her background in gender studies, Narda takes an interdisciplinary approach to rethinking young children's relations with animals, plants, and landscape forms. She works as a pedagogista with UVic Child Care Services, with a particular interest in thinking with processes of rot (compost), death, and waste-flows as a conduit for promoting sustainable and ethical futures with children. Email: nelsonn@uvic.ca
\end{abstract}

Dr. Veronica Pacini-Ketchabaw is a professor of early childhood education in the Faculty of Education at Western University in Ontario, Canada. She is co-director of the Ontario Centre of Excellence in Early Years and Child Care and the British Columbia Early Childhood Pedagogies Network. Her writing and research contributes to the Common Worlds Research Collective (tracing children's relations with places, materials, and other species) and the Early Childhood Pedagogies Collaboratory (experimenting with the contours, conditions, and complexities of $21^{\text {st }}$-century pedagogies). Email: vpacinik@uwo.ca

Dr. Fikile Nxumalo is an assistant professor of early childhood education at the University of Texas at Austin, where she is also affiliated faculty with African and African Diaspora Studies and Native American and Indigenous Studies. Fikile's research interests are centered on environmental and place-attuned early childhood studies that are situated within and responsive to young children's uneven inheritances of anthropogenic, anti-Black, and settler colonial worldings. This scholarship, which is published in journals including Environmental Education Research, Contemporary Issues in Early Childhood, International Journal of Qualitative Studies in Education, and Environmental Humanities, is rooted in perspectives from posthuman, Indigenous, and Black feminisms. Email: fnxumalo@austin.utexas.edu

This paper introduces common worlding approaches in early childhood education as possibilities for situating educational practices within current times of environmental precarity. Particularly, it offers new questions to early childhood nature education practices that reinscribe settler colonial and Euro-Western binary logics.

Key words: early childhood; environmental education; common worlds; settler colonialism
South Park Family School is located in Victoria, British Columbia, a city that is renowned for its proximity to abundant green spaces and surrounding "natural beauty." For the second year in a row, in early January of 2015, the school's nature kindergarten admission process became a greatly anticipated social event. Program enrollment was scheduled to open on a Monday morning. But in a move more often associated with efforts to secure concert seating or meet celebrities, families started lining up the Friday before in the hopes of acquiring one of twenty spots available in the program. People pitched tents and brought provisions and local press reported a festive atmosphere over the wet and cold three-day wait for registration to begin (Bell, 2015; Lam, 2015; Petrescu, 2015). A variety of reasons were cited as motivating factors for camping out on a cold, wet winter weekend, but going to such lengths takes on different proportions when seen as enmeshed in an intensifying societal drive to capitalize on the promise that nature-based education signals in terms of delivering "something different, something better" for children's futures.

While competing for access to coveted educational programs may not be uncommon in any number of North American cities, this event is symptomatic of a much larger and far-reaching contemporary phenomenon. For more than a decade now, nature-based education has been a growth industry in Canada, the United States, and the United Kingdom, as witnessed through the proliferation of forest preschools, nature or coastal kindergartens, garden schools, Tinkergarten $₫$, and other ecocentric curricular options from which predominantly urban families 
can choose (Cairns, 2017; Depenbrock, 2017; Dunu, 2016; Ward, 2014). This trend reflects an increasing desire to reap cognitive, emotional, mental, and physical health benefits associated with putting children "back into nature" (Cox et al., 2017; Louv, 2008), while promoting better stewardship of nature (Russ \& Krasny, 2017; SDG Academy, 2017).

However compelling, these desires also sit within the paradox of what acclaimed scientist and environmental activist David Suzuki (2012) describes as the failure of over fifty years of environmentalism to make significant enough change in the way we relate with the world to stave off the global ecological crisis we now face with other creatures who call this planet home (Heise, 2016). These desires for returning children to nature tend to reinscribe, even if inadvertently, anthropocentric and idealized binary views of children existing in a separate sphere from a so-called natural environment (Taylor, 2013a, 2017b). It is also important to pay attention to the exclusions that make these programs largely inaccessible to historically marginalized communities (Pacini-Ketchabaw, 2013). Thus, a question that is of interest to us in this article is, what are some ways toward firmly situating early childhood education (not just specialized and privileged ecocentric programs) within current ecological challenges and their unevenly distributed impacts? We engage the question, first, by articulating the entangled relations between nature-based programs and settler colonial relations, and second, by offering a brief account of how common world frameworks might address these relations by challenging nature/culture and other imagined conceptual binaries that tend to underscore dominant contemporary environmental educational approaches.

\section{Looking Within Pedagogical Practices}

Of course, encouraging sustainable futures is of central concern to educators, practitioners, and researchers working in the field of environmental education (Russ \& Krasny, 2017). This article is not intended to criticize ongoing efforts to work toward positive change with young children. Nor are we against spending time with young children outdoors, growing food together, or attuning ourselves to our relations with plants, animals, and others we share places with. Rather, we are deeply concerned with what we see as a refusal to step back from the field's dual obsession with recreating a(n) (imagined) state of environmental sanctity and enhancing children's developmental progress. We are interested in the potentials of looking within our pedagogies and practices and attendant complicities in promoting the very conditions we seek to change. In particular, we are concerned with the persistent colonialist and capitalist values that continue to permeate popularized early childhood environmental education frameworks in North America. These frameworks perpetuate the construction of early education as a market to compete for scarce resources; "resources" that include dwindling "nature spaces" to cultivate a "closeto-nature" child (Louv, 2008). What taken-for-granted attitudes and beliefs might be normalized through early childhood education practices? And, have we stopped to think about the way such approaches might shore up colonial and capitalist worldviews?

In this article, we interrogate some of the deeply embedded exclusions and anthropocentric hierarchies in mainstream environmental education to invite consideration of several questions, including these: What else might be possible in pedagogy and practice with young children? What might happen when educators risk trying new ways of doing and thinking environmental education with young children in ways that refuse the binary logics underlying colonial ways of seeing and doing in the world? How might pedagogical practices move away from positioning plants, animals, and landscape forms as static resources for human benefit? What might it look like to take seriously the need for different kinds of pedagogical relationships with children, families, and more-thanhuman others with whom we co-inhabit the places and spaces of early childhood education? Actively challenging the Euro-Western epistemological bedrock, including the hierarchical binaries used to justify the violent removal of Indigenous peoples from their homelands for settler colonial expansion and resource extraction, feels like an 
imperative part of this process. This extractive worldview paves the way for continued cultural and racialized injustices and is an intrinsic force behind the alarming pace of narrowing ecological and cultural futures for all of Earth's inhabitants (Davis \& Todd, 2017).

\section{Better for Whom?}

We wonder about the worldview perpetuated through dominant framings of contemporary nature-based education. If, as van Dooren, Kirksey, and Münster (2016) suggest, the point of shifting attunement in educational practice is to "[craft] better possibilities for shared life" (p. 9), we feel it is vital to ask ourselves if we have adequately addressed the question of "better for whom?" Indigenous techno-science scholar Kim TallBear (2015) argues that modern eco-anxieties, such as those deployed through the proliferation of nature education programs, are a moment of settler colonial awakening to what Indigenous peoples in North America have experienced over the last 150 years of colonization. Our concern about the persistence of Euro-Western colonial logics in mainstream environmental educational frameworks is more than simply "abstract" or "theoretical." We see these logics as actively undermining everyday possibilities for radically reimagining what it means to live in relational reciprocity with one another and the plants, animals, water, and landscape forms that we are, in fact, dependent on for our very existence. Whose futures might we be diminishing in the processes of privileging some bodies and not others through early learning pedagogies and practices? We are interested in exploring what happens when we locate our pedagogical intentions at the crossroads of colonial relations and environmental education (Pacini-Ketchabaw, Nxumalo, Kocher, Sanchez, \& Elliot, 2015).

The momentum generated by nature-based education's growing popularity is striking. We see the tendency to frame nature-based pedagogies as a curative means for optimizing childhood development and promoting ecostewardship (Louv, 2008) as symptomatic of an increasing desire to make hopeful connections in an era rife with negative messaging about humanity's role in creating catastrophic times. However, we wonder what other connections are being overshadowed by preoccupations with child-centered benefits? An awareness of the way we tell stories about children's engagements with the land and its more-than-human inhabitants is necessary to avoid promoting nature-based education as a codified means for achieving transcendence from material, historical, and socioeconomic connections to inequity and injustice. For example, Katie Cairns (2017) calls attention to the way socioeconomic privilege shapes dominant school gardening stewardship and salvation narratives:

The stewardship narrative centres on a lush school garden that has the support of well-resourced institutions and affluent parents' councils. In this context, gardening is constructed as enriching children's learning and providing opportunities for them to "give back" to the community. This privileged space is constructed differently from a state- or foundation-funded initiative to bring school gardens into poor, inner-city communities, where students are labeled "at-risk" and in need of saving from their local circumstances. In both these settings, the benefits of the garden are celebrated, but they are defined in relation to a different set of perceived problems, and with the support of different material resources and cultural narratives about childhood, food, and futurity. (p. 315)

According to Cairns, promoting urban gardening as a conduit for realizing a child's individual transformation obscures a cultural tendency to valorize middle- and upper-class children "getting their hands dirty" while neglecting connections between their privileged location and the way they continue to benefit from the marginalization of racialized migrant labourers, "lunch ladies," and others who grow food, prepare healthy meals, and serve these same children (p. 311). 
In our view, settler colonialism is also profoundly damaging to both Indigenous and non-Indigenous children and their families in its utilization of racism, sexism, classism, hetero-normativity, and other tools to shape the world in accordance with white supremacist and neoliberal values (Pacini-Ketchabaw, 2013; Pacini-Ketchabaw \& Nxumalo, 2015. Thus, ethico-political educational practices need to build better understandings of the devastating effects caused by the ongoing processes of colonization on Indigenous lands and the way these processes undermine Indigenous communities' rights to self-determination and abundant futures. Further to this point, referring to the entanglements of pervasive anti-Blackness and settler colonialism, Kristen Simmons (2017) powerfully makes visible what she calls "settler atmospherics" as "the normative and necessary violences found in settlementaccruing, adapting, and constricting Indigenous and Black life in the U.S. [and Canadian] settler state[s]" (para. 4). For instance, as witnessed recently on the traditional territories of the Tsleil-Waututh, Squamish, and Coldwater First Nations and the Dakota and Lakota peoples at Standing Rock Sioux Reservation, Indigenous peoples have led major resistance movements to government and industry attempts to build large-scale pipeline, mining, and damming projects, including putting themselves on the front lines of defending water, land, and air. Anishinaabe author and activist Winona La Duke (2015) points to state-sanctioned attempts to militarize Indigenous lands as manifestations of behaviours that are indicative of an oil-addicted society that relies on a willingness to retool the infrastructure of the North American continent for settler colonial gain.

Within this context, have we paused to ask ourselves how being part of a fossil-fuel-addicted society might be manifesting itself in early childhood nature pedagogies? How might these pedagogies, for example, rely on colonial discovery narratives of empty "nature spaces" devoid of Indigenous cultural, economic, and spiritual connections? What counts as nature in settler colonial spaces and places (Collard, Dempsey, \& Sundberg, 2014)? How is settler colonialism embedded in dominant discourses of putting "innocent children back into nature" (Nxumalo, 2015; Taylor, 2017b)? Furthermore, how are constructions of childhood innocence racialized in these so-called return to nature discourses (Nxumalo, 2018)? How might some of the narratives we nurture in early childhood education be implicated in processes of normalizing continued resource extraction? Perhaps it is possible to interrupt underlying assumptions about land as an inert resource for corporate profit. What does it mean to take seriously the responsibility of foregrounding the places we now live and learn with young children as Indigenous lands? While we offer no easy answers to these questions, we suggest that thinking collectively about such issues in early childhood education might create movement beyond preoccupations with individual children's well-being or some imagined idealized future state of improved eco-stewardship.

\section{Common Worlding Frameworks}

Taking inspiration from Isabelle Stengers' (2008) example of experimenting with "refrains," we work with this historical moment in environmental education as an opportunity "to make perceptible the "working forces" that "the modern [colonial] territory shelters" (p. 42). We hope to move beyond the trappings of "eco-absolution" or the belief that being on the "right" side of serious ecological debates inoculates our practices from the possibility of perpetuating harmful patterns of relating. In the face of ongoing Indigenous resistance in North America to the intensified push to build pipelines, big dams, and other highly destructive industrial projects, we feel that now, more than ever, it is vital to confront some of the deeply ingrained colonial preoccupations within our field. In other words, it is timely and increasingly urgent that researchers and educators in early childhood education engage in crafting new ways of responding to these colonial and ecologically challenging times.

We find a common worlds framework productive and generative to begin this creative process. Common worlds consist of the full range of complex relationships, traditions, and legacies that we inherit in the specific places in which we live. These include our relationships with our immediate natural and built environments, with the 
other human and nonhuman beings that share these same environments, and, in settler societies such as Canada, with complex cultural, racialized, colonial, and environmental historical traditions and legacies (Taylor \& PaciniKetchabaw, 2016). Common worlds frameworks are characterized by an attempt to move beyond pedagogical practices that confine themselves to exclusively human (or social) concerns and interests. Instead they assume that human becomings and even sociality itself are entangled in complex, often asymmetrical ways with the being and becoming of other species (Taylor, 2017a). It is the lively connections among species (often, but not always, including humans), their collective effects, and their ethical implications that provide pedagogical focus (Taylor, 2013, 2017a).

As our colleague Affrica Taylor (2013a, 2017a) explains, within the context of early childhood education (where we are located), common worlds are the actual, messy, unequal, and imperfect worlds children inherit and co-inhabit along with other human and nonhuman beings and entities. Thus, this framework challenges the concepts of childhood innocence, purity, and protection that are premised on a belief that childhood can be separated off from the rest of the world. Within this framework, childhood is approached as situated, collective, and relational rather than as a universal developmental life stage that is experienced individually. Children do not just grow up in a society, but they grow up in a world, and the world affects and acts on them-even as they act on it (Taylor, 2017b).

The first major publication promoting a common world approach to childhood was Taylor's 2013 Reconfiguring the Natures of Childhood. In this text, Taylor suggests common worlds as a framework to move beyond humancentric concerns-and to resist the nature/culture divide that separates us (and children) from entangled human and nonhuman issues and concerns. The central question within a common worlds approach has clear political and ethical framings. It asks: How do we live well together in the more-than-human common worlds we inherit? It responds to the considerable challenge of finding ways in which all (the human and the more-than-human) can flourish in the face of incommensurable differences, confronting losses and uncertain ecological futures (Taylor, 2013a, 2017b). Importantly, within common worlds, the category of human is not a flattening of human difference; it includes an attunement to the stratifications of the human, including the ways in which racialized people continue to be dehumanized both within and outside of early learning contexts (Nxumalo, 2018). Because the lives and futures of $21^{\text {st }}$-century children are affected by the entwined ongoing social and ecological impacts of colonialism, racisms, and the excesses of capitalist modernity, common worlds researchers agree that it is imperative to rethink humans' place in the world and human's relations with earth others-particularly in pedagogical discussions on the Anthropocene (Taylor, 2017b).

Rather than foreclosing on what might constitute common worlds, we put forward a generative understanding of common worlds as always in the process of composition (Taylor, 2013a). Central to the notion of common worlds is the recognition that humans are not the sole composers or caretakers of the commons. This is very similar to Donna Haraway's notion of "worlding," or the more-than-human process of making worlds that she describes as a process of becoming worldly with other species (Haraway, 2008; 2016). Drawing on Haraway's notion of worlding, Taylor's common world pedagogies challenges educators to learn to inherit and co-inhabit our entangled, colonial, and unequal multispecies worlds and to respond and act in these worlds in ways that allow humans and morethan-humans to flourish (Taylor, 2013b).

Unlike nature-based education, common world framings promise no salvation from, nor techno-fixes and grand solutions to, the ecological challenges we face (Taylor, 2017a). Instead, inspired by feminist practices, common worlding involves attending to the small, mundane, seemingly insignificant everyday relations in our immediate common worlds and staying with the trouble that these entangled worlds bring (Taylor, 2015). Over the last few years, we have been collectively experimenting with modes of attunement to children's entangled, messy, and 
uneven relations with more-than-human worlds in particular places and spaces of early childhood education (Haro Woods et al., 2018; Nelson, 2018; Nelson, Coon, \& Chadwick, 2015; Nxumalo \& Pacini-Ketchabaw, 2017; Pacini-Ketchabaw, Taylor, \& Blaise, 2016; Taylor \& Pacini-Ketchabaw, 2015). We approach our research practices as political acts of common worlding, as collective and compositional practices that not only account for the other species with whom we live but acknowledge that these dynamic entangled multispecies relations gestate our common worlds and bring them into being. Common worlds methods are characterized by an attempt to move beyond research practices that confine themselves to exclusively human (or social) concerns and interests.

Our attempts to interrupt binaries, colonialisms, racisms, and other "isms" using common worlding framing have had their own challenges that we are always aware of and try to work with. However, it is not about "getting it right." For us, the challenge continues to be to keep common worlds framings open to a range of articulations, a range of challenges, a range of relations, and a range of not-yet possibilities. How might we compose pedagogies that attend to human and nonhuman constituents, all exercising agency? What might pedagogies need to look and feel like to make them capable of resisting an anthropocentric frame of reference? Or, of creating ones that consider the limits of human perception and communication? How might we compose pedagogies that take risks and stay open to interdeterminacies and resist human control (Tsing, 2014)?

It is important to note here that while increasingly being taken up by scholars in a variety of disciplines, many of these ideas are not new. In particular, Indigenous knowledges for millennia have recognized the inextricable reciprocal entanglements between human and more-than-human others (TallBear, 2015). Therefore, our focus on relationality is resonant with Indigenous relational onto-epistemologies that have never separated nature from culture and that foreground reciprocal relations with more-than-human others (Todd, 2015; Tuck \& McKenzie, 2014; Watts, 2013). How might educators compose pedagogies that focus on uneven relations rather than on individual children? For example, what might it look like to respond to the absenting of Indigenous life and connectedness with more-than-human relations with young children within settler colonial contexts? One possibility is to seek out ways to actively foreground specific Indigenous presences and land relationships in the specific places and spaces of early childhood education.

Drawing inspiration from the decolonizing potentials of presencing (Simpson, 2011) as modes of countering Indigenous erasure can take early childhood practices in multiple generative directions. This includes careful attunement to what and whose stories of particular place are seen to matter in children's encounters with the natural world (Nxumalo, 2015). Speaking to the need for ethical inclusion of Indigenous theories, stories, and experiences in Anthropocene contemporary environmental discourse, Red River Métis (otipemisiw, Michif) scholar Zoe Todd (2015) is helpful to think with in regards to thinking about how and whose stories matter in our early years pedagogies and practice. Todd writes:

As an Indigenous scholar working in both Canada and the UK, I am intensely aware of how discourse is deployed within and between geographies, disciplines, and institutions. Whenever a term or trend is on everyone's lips, I ask myself: "What other story could be told here? What other language is not being heard? Whose space is this, and who is not here?" ... And, finally, who is dominating the conversations about how to change the state of things? (p. 244)

Educators within their particular context can work to challenge settler colonial discourses of the "wild" outdoors as empty land on which children inscribe their meanings and learning. They can pose the question of what it might look like in practice to take seriously that "Indigenous land, life and futures are deeply entangled and coconstitutive" (Todd, 2017, n.p.)? One mode of engagement is to seek out marginalized human and more-thanhuman stories of the places educators encounter with children, to carefully consider who can tell certain stories 
and to avoid and challenge stories that perpetuate Indigenous erasure.

\section{Compost, Pipelines, and Childhood: Common World Narratives}

Returning to the earlier question of how we might interrupt colonial assumptions about land as an inert resource for corporate profit in our pedagogies and practice, we offer the following as a moment of reflection from everyday practice from a West Coast early childhood centre compost inquiry project. Within the wider context of climate change and fossil fuel debates in contemporary North American society, this moment from practice foregrounds pipelines as an ongoing area of contention on the unceded territories of the Tsleil-Waututh, Squamish, and Coldwater First Nations, as well as other Coast and Straits Salish peoples in what is now British Columbia, Canada (Nxumalo, 2017; Rowe et al., 2017). Recently approved pipelines to transport unrefined oil from Alberta's tar sands (McLeod, 2016) that would put Indigenous lands at risk have sparked resistance from several groups of people: Indigenous water and land protectors, environmental activists, faith groups, federal, provincial, and municipal government officials. To date, 176 people have been arrested at the Burnaby Mountain Kinder Morgan terminal site, with many local residents joining the protests because they do not want the pipeline to pass near their homes (Anderson, 2018). Amid some divergent interests, these different groups are allied by mutual concerns about the potential environmental effects of an oil spill both along pipeline routes and at ocean inlets that would see a large increase in tanker traffic.

The specificities of Kinder Morgan pipeline debates reflect the wider contemporary context of proposed major infrastructure projects that have been igniting public debate and large-scale acts of resistance by some Indigenous groups in defense of their lands and by non-Indigenous environmental activists as well. Dakota Access Pipeline, Muskrat Falls, Site C, and the now defunct Northern Gateway project all come to mind as part of the intensified attempts to push through heavily contested projects despite the outcry of countless people. Sometimes, these political and, indeed, moral debates surface through practice in quite explicit ways. For example, one day, children and educators in one of the centres we work with were shredding newspaper to help make bedding for a worm composting bin. One of the educators later described a moment she shared with the children wherein they wanted to know what the newspaper they were ripping up said. She made the decision to read some of the paper with the children, including stories about pipeline strife, which led to a brief conversation, questions, and sharing of the children's opinions about what was happening in their wider common worlds. Connections to our wider political implications are also made more implicit through the process of pedagogical narration and personal reflection, as seen in the following piece:

A few children and educators separate the last of the food remnants and castings from the concentrations of lying-at-the-bottom-of-the-bin worms. Sherri-Lynn (educator) and a large group of children tear long strips of newspaper to make new bedding. This "menial" task turns political when a child asks what the newspaper says. Sherri-Lynn reads the headlines:

Kinder Morgan decisions,

DAPL debates,

Standing Rock acts of Indigenous resistance...

In this moment, the inquiry intention to think of compost-cum-soil communities as more than resources for our curiosity and benefit moves into a wider political realm. More questions are raised, opinions expressed, while the newspaper shredding resumes. What might paying attention 
to new, even deeply unsettling modes of relating that invite discussion about the politics and power inherent in the processes and practices of our ways of relating open up for/with young children in practice?

\section{Temporary Closings}

These are, without a doubt, unsettling times to be living and teaching in. While coupling romanticized notions of children in nature with the richness of nature-based experiences may soothe eco-anxieties, the demand for land-based education cannot be separated from ongoing settler colonial processes in what is currently Canada. Thus, we foreground our concerns with "back to the land" approaches to early childhood education in stewardship discourses. In particular we ask, Whose land are we getting back to, and who is the "we" that gets to return to the land? Colonial forces forcibly removed Indigenous peoples from the places where we now situate a new generation of eco-stewards-in-the-making. Images of predominantly white, middle-class children situated in "pristine nature" used to promote nature-based programs inadvertently serve as a neocolonial repackaging of the notion of terra nullius and settler colonial emplacement (Taylor, 2013). This violent erasure and settler replacement, even as it emerges in seemingly benign ways, is fundamental to the contemporary workings of settler colonialism (Tuck \& Gaztambide-Fernández, 2013).

In this paper, we have introduced some of the ways we have been thinking and acting with common worlding frameworks as potential challenges to the colonial assumptions that underpin normative environmental approaches in early education. There is no prescriptive "how-to" for this work, and we continue to work toward new understandings of what this looks like in our everyday practices with young children. Nonetheless, our hope is that thinking with common worlds approaches might be an opening toward unsettling conversations in environmental education for young children. 


\section{References}

Anderson, D. (2018, April 4). Arrests to continue as Kinder Morgan protests heat up: "There will be a lot more people who are willing to occupy the injunction zone." The Tyee. Retrieved from https://thetyee.ca/News/2018/04/04/Kinder-Morgan-Protest-Arrests/

Bell, J. (2015, January 12). Victoria nature kindergarten filled quickly by campers. Times Colonist. Retrieved from http://www.timescolonist. com/news/local/victoria-nature-kindergarten-filled-quickly-by-campers-1.1728775

Cairns, K. (2017). Connecting to food: Cultivating children in the school garden. Children's Geographies, 15(3), 304-318. Retrieved from http://www.tandfonline.com/eprint/AsVu5gRtxzf8RcvrZ8JS/full

Collard, R., Dempsey, J., \& Sundberg, J. (2015). A manifesto for abundant futures. Annals of the Association of American Geographers, 105(2), 322-330. doi: 10.1080/00045608.2014.973007

Cox, D. T. C., Shanahan, D. F., Hudson, H. L., Plummer, K. E., Siriwardena, G. M., Fuller, R. A., Anderson, K., Hancock, S., \& Gaston, K. J. (2017). Doses of neighbourhood nature: The benefits for mental health of living with nature. BioScience, 67(2), 147-155. doi: 10.1093/biosci/biw173

Davis, H. M., \& Todd, Z. (2017). On the importance of a date, or decolonizing the Anthropocene. ACME: An International Journal for Critical Geographies, 16(4), 761-780. Retrieved from https://www.acme-journal.org/index.php/acme/article/view/1539

Depenbrock, J. (2017, January 17). At "nature preschools," classes are outdoors. Education Week. Retrieved from http://mobile.edweek. org/c.jsp?cid=25919881\&bcid=25919881\&rssid=25919871\&item=http\%3A\%2F\%2Fapi.edweek.org\%2Fv1\%2Few\%2F\%3Fuuid \%3D12D9D840-D9BB-11E6-BE7B-3FDCB3743667\&cmp=SOC-SHR-facebook

Dunu, C. (2016, July 5). Kindergartens in the forest allow children to synch with nature. Epoch Times. Retrieved from http://www. theepochtimes.com/n3/2102564-kindergartens-in-the-forest-sync-children-with-nature/

Haraway, D. J. (2008). When species meet. Minneapolis, MN: University of Minnesota Press.

Haro Woods, Nelson, N., Yazbeck, S. L., Danis, I., Elliott, D., Wilson, J., Payjack, J., \& Pickup, A. (2018). With(in) the forest: (Re) conceptualizing pedagogies of care. Journal of Childhood Studies, 43(1).

Heise, U. K. (2016). Imagining extinction: The cultural meanings of endangered species. Chicago, IL: University of Chicago Press.

La Duke, W. (2015, October 26). Keystone pipeline on Indigenous lands? Retrieved from http://ifg.org/techno-utopia/program/

Louv, R. (2008). Last child in the woods: Saving our children from nature-deficit disorder ( $2^{\text {nd }}$ ed.). Chapel Hill, NC: Algonquin.

McLeod, A. (2016, November 29). Trudeau gov't approves two major pipeline projects, vows tanker bans. The Tyee. Retrieved from https://thetyee.ca/News/2016/11/29/Kinder-Morgan-Approved/

Nelson, N. (2018). Common worlding pedagogies: Cultivating the "arts of awareness" with tracking, compost, and death (Master's thesis). Retrieved from https://dspace.library.uvic.ca/handle/1828/9341

Nelson, N., Coon, E., \& Chadwick, A. (2015). Engaging with the messiness of place in early childhood education and art therapy: Exploring animal relations, traditional hide, and drum. Canadian Children, 40(2), 43-56.

Nxumalo, F. (2015). Forest stories: Restorying encounters with "natural" places in early childhood education. In V. Pacini-Ketchabaw \& A. Taylor (Eds.), Unsettling the colonial places and spaces of early childhood education (pp. 21-42). New York, NY: Routledge.

Nxumalo, F. (2017). Geotheorizing mountain-child relations within anthropogenic inheritances. Children's Geographies, 15(5), 558-569. doi: 10.1080/14733285.2017.1291909

Nxumalo, F. (2018). Situating Indigenous and Black childhoods in the Anthropocene. In A. Cutter-Mackenzie, K. Malone, \& E. Barratt Hacking, (Eds.), International research handbook on childhoodnature: Assemblages of childhood and nature. New York, NY: Springer. doi: 10.1007/978-3-319-51949-4_37-2

Pacini-Ketchabaw, V. (2011). Rethinking developmental theories in child and youth care. In A. Pence \& J. White (Eds.), Child and youth 
care: Critical perspectives on pedagogy, practice, and policy (pp. 19-32). Vancouver, BC: UBC Press.

Pacini-Ketchabaw, V. (2013). Frictions in forest pedagogies: Common worlds in settler colonial spaces. Global Studies of Childhood, 4(1), 355-365. doi: 10.2304/gsch.2013.3.4.355

Pacini-Ketchabaw, V., \& Nxumalo, F. (2015). Unruly raccoons and troubled educators: Nature/culture divides in a childcare centre. Environmental Humanities, 7, 151-168. doi: 10.1215/22011919-3616380

Pacini-Ketchabaw, V., Nxumalo, F., Kocher, L., Elliot, E., \& Sanchez, A. (2015). Journeys: Reconceptualizing early childhood practices through pedagogical narration. North York, ON: University of Toronto Press.

Pacini-Ketchabaw, V., Taylor, A., \& Blaise, M. (2016). Decentring the human in multispecies ethnographies. In C. Taylor \& C. Hughes (Eds.), Posthuman research practices in education (pp. 149-167). London, UK: Palgrave Macmillan.

Pacini-Ketchabaw, V., Taylor, A., Blaise, M., \& de Finney, S. (2015). Learning how to inherit in colonized and ecologically challenged life worlds in early childhood education: An introduction. Canadian Children, 40(2), 3-8.

Petrescu, S. (2015, January 10). Parents camp out to nab spot in nature kindergarten. Times Colonist. Retrieved from http://www. timescolonist.com/news/local/parents-camp-out-to-nab-spot-in-nature-kindergarten-1.1727181

Rowe, J., Shaw, K., Ban, N., Caradonna, J., Curran, D., Lantz, T., Peredo, A.M., Simpson, M., \& Smith, T. (2017, February 16). Comment: First Nations show leadership in pipeline debates. Times Colonist. Retrieved from http://www.timescolonist.com/opinion/oped/comment-first-nations-show-leadership-in-pipeline-debates-1.9989449

Russ, A., \& Krasny, M. E. (Eds.). (2017). Urban environmental education review. New York, NY: Cornell University Press.

SDG Academy. (2017). The best start in life: Early childhood development for sustainable development. [online MOOC]. Retrieved from https://courses.sdgacademy.org/learn/the-best-start-in-life-early-childhood-development-for-sustainable-developmentfebruary-2017

Simmons, K. (2017, November 20). Settler atmospherics. Dispatches. Cultural Anthropology website. Retrieved from https://culanth.org/ fieldsights/1221-settler-atmospherics

Simpson, L. (2011). Dancing on our turtle's back: Stories of Nishnaabeg re-creation, resurgence, and a new emergence. Winnipeg, MB: Arbeiter Ring.

Stengers, I. (2008). Experimenting with refrains: Subjectivity and the challenge of escaping modern dualism. Subjectivity, 22(1), 38-59.

Suzuki, D. (2012, May 3). The fundamental failure of environmentalism. [blog post]. Retrieved from http://www.davidsuzuki.org/blogs/ science-matters/2012/05/the-fundamental-failure-of-environmentalism/

TallBear, K. (2015, December 15). Matters of life and death. [video file]. Retrieved from https://www.youtube.com/watch?v=tjiVcwpBhSc

Taylor, A. (2013a). Reconfiguring the natures of childhood. New York, NY: Routledge.

Taylor, A. (2013b, September). Educating for sustainable common worlds at the eve of the Anthropocene. Lecture for University of Western Sydney Spring School for Sustainability, Sydney, Australia.

Taylor, A. (2017a). Beyond stewardship: Common world pedagogies for the Anthropocene. Environmental Education Research, 23(10), 1448-1461. doi: 10.1080/13504622.2017.1325452

Taylor, A. (2017b). Romancing or re-configuring nature in the Anthropocene? Towards common worlding pedagogies. In K. Malone, S. Truong, \& T. Gray (Eds.), Reimagining sustainability in precarious times (pp. 61-75). Singapore: Springer.

Taylor, A., \& Pacini-Ketchabaw, V. (2015). Learning with children, ants, and worms in the Anthropocene: Towards a common world pedagogy of multispecies vulnerability. Pedagogy, Culture, \& Society, 23(4), 507-529. doi: 10.1080/14681366.2015.1039050

Todd, Z. (2015). Indigenizing the Anthropocene. In H. Davis \& E. Turpin (Eds.), Art in the Anthropocene: Encounters among aesthetics, politics, and epistemologies (pp. 241-254). London, UK: Open Humanities Press. 
Todd, Z. (2017). Commentary: The environmental anthropology of settler colonialism, Part I. Environment and Anthropology Society Engagement blog. Retrieved from https://aesengagement.wordpress.com/2017/04/11/commentary-the-environmentalanthropology-of-settler-colonialism-part-i/

Tsing, A. (2014). More-than-human sociality: A call for critical description. In K. Hastrup (Ed.), Anthropology and nature (pp. 27-40). New York, NY: Routledge, Taylor \& Francis Group.

Tuck, E., \& Gaztambide-Fernández, R. A. (2013). Curriculum, replacement, and settler futurity. Journal of Curriculum Theorizing, 29(1), $72-89$.

Tuck, E., \& McKenzie, M. (2014). Place in research: Theory, methodology, and methods. New York, NY: Routledge.

van Dooren, T., Kirksey, E., \& Münster, U. (2016). Multispecies studies: Cultivating arts of attentiveness. Environmental Humanities, 8(1), 1-23. doi: $10.1215 / 22011919-3527695$

Ward, L. (2014, May 13). How can teachers introduce forest school principles to their curriculum? The Guardian. Retrieved from https:// www.theguardian.com/teacher-network/teacher-blog/2014/may/13/teachers-forest-school-principles-curriculum?

Watts, V. (2013). Indigenous place-thought and agency amongst humans and non humans (First Woman and Sky Woman go on a European world tour!). Decolonization: Indigeneity, Education, \& Society, 2(1), 20-34. 